\title{
Genetic Analysis of Quantitative and Quality Traits in Okra under Sub- Temperate Conditions of North-Western Himalayas
}

\author{
Amandeep Kaur*, Sonia Sood, V.K. Sood, Sanjay Chadha and Akhilesh Singh \\ Department of Vegetable Science and Floriculture, College of Agriculture, CSK Himachal \\ Pradesh Krishi Vishvavidyalaya, Palampur (HP)-176 062, India \\ *Corresponding author
}

\section{A B S T R A C T}

\begin{abstract}
The present investigation was carried out to generate information on variability for quantitative and quality traits in okra [Abelmoschus esculentus (L.) Moench]. The experiment material consisted of 30 genotypes of okra that were evaluated in Randomized Complete Block Design (RCBD) during summer-rainy season, 2018. The observations were recorded on days to 50 per cent flowering, node at which the first pod set, plant height $(\mathrm{cm})$, nodes per plant, internodal length $(\mathrm{cm})$, days to marketable maturity, pod length $(\mathrm{cm})$, pod diameter $(\mathrm{cm})$, ridges per pod, average pod weight $(\mathrm{g})$, pod yield per plant $(\mathrm{g})$, pods per plant, duration of availability of edible pods, dry matter (\%), mucilage (\%), immature pod colour and pod pubescence. Significant differences were observed among the genotypes for all the traits, indicated presence of sufficient variation. Among all, genotypes 9801, Kashi Vibhuti, DPO-5, Palam Komal and Punjab Suhawani were the highest yielders and these were also among the top genotypes for economic traits viz., nodes per plant, internodal length, days to marketable maturity, duration of availability of edible pods and pods per plant. The PCV was invariably higher than their corresponding GCV for most of the characters, indicated close association between phenotype and genotype. High to moderate PCV as well as GCV was observed for mucilage followed by pods per plant, pod yield per plant, average pod weight, ridges per pod, node at which the first pod set, nodes per plant, plant height and internodal length depicting the presence of substantial variability and would respond better to selection. High heritability along with high genetic advance was observed for ridges per pod, mucilage and pod yield per plant, respectively revealing the importance of additive gene action for the inheritance of these traits, and further improvement could be done through phenotypic selection.
\end{abstract}

\section{Introduction}

Okra [Abelmoschus esculentus (L.) Moench; $2 \mathrm{n}=130]$ commonly known as lady's finger or bhindi belongs to the family Malvaceae and is one of the most important warm season fruit vegetables grown in tropical and sub-tropical regions of world including West Africa, South-East Asia, Southern United States of America, Brazil, Turkey and North Australia. It is one of the three species of the genus
Abelmoschus used for cultivation, the other two being Abelmoschus manihot (L.) Medikus and Abelmoschus moschatus (Medikus). Okra is native to Ethiopia with secondary center of origin in India (Vavilov, 1951). However, according to recent reports it is considered of African or Asiatic origin (Markose and Peter, 1990). Okra is a multipurpose vegetable grown mainly for its tender, immature, nonfibrous edible pods; sometimes leaves, buds and flowers may also be consumed (Martin et 
al., 1981 and Martin, 1982). Tender immature pods are used in a variety of ways as cooked vegetables, boiled or fried, soups, sauces, stews in meat, frozen, canned and dehydrated products. It is also used in thickening of soups and gravies because of its high mucilage content. Its ripe seeds can be dried, roasted and ground to be used as a coffee substitute (Gemede et al., 2015) besides being rich in protein (Karakoltisdis and Constandinides, 1975). The oil from its seeds is utilized in perfume industry (Clopton et al., 1948). The dried pod shell and stem containing crude fibre are used in paper industry. For a year round consumption, sun dried, frozen and sterilized pods of okra are also important market products.

The green pods are rich in vitamins (A, B and $\mathrm{C})$, proteins, calcium magnesium, phosphorus, iron and other minerals. It also contains iodine and is, therefore, recommended for the treatment of goitre. Mucilage and fibre content present in okra helps in lowering down the glucose level in blood and therefore benefits diabetic patients. Due to high nutritive value and long post-harvest life, okra has captured a prominent position among export vegetables. It has a vast potential to earn foreign exchange and accounts for 60 per cent export of fresh vegetables excluding potato, onion and garlic. The important export destinations are Middle East, United Kingdom, Western Europe and USA. Frozen bhindi is also exported to United Kingdom. Major exporting areas in India are Nasik, Ozar, Saikheda, Dindori, Kolhar, Naraingaon and Sholapur in Maharashtra (Thamburaj and Singh, 2001). Globally, okra is grown in an area of $11,17,806$ hectares with a production of $87,06,312$ tonnes and 7.8 tonnes/ha productivity (Anonymous, 2016a). India ranks first in the world with annual okra production of $60,95,000$ tonnes produced from $5,09,000$ hectares area with a productivity of 11.97 tonnes/ha (Anonymous, 2018). In Himachal Pradesh, it is grown during summer and rainy season in foot and mid hills and occupies an area of 2,950 hectares with a production of 39,360 tonnes (Anonymous, 2017). Being one of the important cash vegetables of the state, it fetches lucrative returns to the growers.

In Northern Indian Plains, usually two crops i.e. spring-summer and rainy season are raised. The spring-summer crop is sown from the beginning of February till end of March. The rainy season crop is sown from May to July. In the hills, the crop is sown from May to June (Anonymous, 2016b). There is a need to breed varieties of okra, which are high yielding and superior to existing varieties. Raising varieties of okra with superior marketable and breedable attributes is not a simple task. However, comprehensive variability in available okra germplasm can prove to be of immense help in achieving these aims. To enhance productivity genetic restructuring of okra germplasm is needed to develop high yielding varieties/hybrids.

To develop superior and disease resistant cultivars of okra, assessment of genetic diversity in the available gene pool is of utmost importance (Morey et al., 2012). Parameters like phenotypic and genotypic coefficient of variation (PCV and GCV) are useful in detecting the amount of variability present in the available genotypes and for framing of breeding strategies. The usefulness of selection depends on the amount of genetic variation present (Adunga and Labuschangne, 2003). A large amount of variability increases the chance of selecting desired types (Vavilov, 1951). Most traits of interest to plant breeders are quantitative in nature and influenced by environment for their expression. According to Fisher, (1918), quantitative traits exhibiting continuous variation are under control of heritable and non-heritable factors. Response to selection depends on the relative proportion of the heritable component in the continuous 
variation. The heritable component is due to genotype, whereas the non-heritable portion is mainly due to environmental factors. Assessment of genotypes is possible through assessment of phenotypic expression, the results of genotype, and the environmental expression. Heritability and genetic advance help in determining the influence of the environment in the expression of the characters and extent to which improvement is possible through selection (Robinson et al., 1949). Higher the heritable variation, greater will be the possibility of fixing the characters by selection methods. Therefore, the present investigation was undertaken to assess the genetic variability for important quantitative and quality traits for genetic improvement of okra.

\section{Materials and Methods}

The present investigation was envisaged to gather information about the potential and characteristics of the experimental material of okra at the Experimental Farm, Department of Vegetable Science and Floriculture, College of Agriculture, CSK Himachal Pradesh Agricultural University, Palampur (HP) during summer-rainy season of 2018.

\section{Experimental site}

\section{Location}

The experimental site is located at an altitude of about $1290.8 \mathrm{~m}$ above mean sea level. Geographic position of the experimental site lies between $32^{\circ} 6^{\prime} \mathrm{N}$ latitude and $76^{\circ} 3^{\prime} \mathrm{E}$ longitude under mid hill zone of Himachal Pradesh, India.

\section{Climate}

The climate is humid sub-temperate. The mean monthly minimum and maximum temperature varied between 2.0 to 22.0 and
9.5 to $34.5{ }^{\circ} \mathrm{C}$, respectively during the cropping season. The experimental site experienced average rainfall of $250 \mathrm{~cm}$ annually, out of which about $80 \%$ is received during monsoon period.

Monsoon arrives in the second fortnight of June and ends in September. The summer is mild and winter is very severe.

\section{Soil}

The soil of the experimental block was acidic with $\mathrm{pH}$ ranging from 5.0 to 5.6 and soil texture is silty clay to silty loam.

\section{Experimental materials}

The experimental materials comprised of 30 genotypes of okra (Table 2).

\section{Experimental design and layout plan}

The trail was laid out on June 5, 2018 comprising of 30 genotypes of okra planted in Randomized Complete Block Design (RCBD) with three replications in plot size of $2.7 \times 1.95$ $\mathrm{m}$. The genotypes were spaced at $45 \mathrm{~cm}$ between row to row and $15 \mathrm{~cm}$ plant to plant. The experiment field was prepared by ploughing twice with power tiller upto a depth of $20 \mathrm{~cm}$ followed by levelling. The Farm Yard Manure (10 t/ha) was mixed in the soil at the time of field preparation with first ploughing.

The chemical fertilizer $\left(75 \mathrm{~kg} \mathrm{~N}, 60 \mathrm{~kg} \mathrm{P}_{2} \mathrm{O}_{5}\right.$ and $60 \mathrm{~kg} \mathrm{~K} \mathrm{~K}_{2} \mathrm{O} / \mathrm{ha}$ ) were applied as basal dose at the time of final field preparation. Half of $\mathrm{N}$, full dose of $\mathrm{P}_{2} \mathrm{O}_{5}$ and $\mathrm{K}_{2} \mathrm{O}$ is applied at the time of final field preparation. Remaining half of $\mathrm{N}$ was top dressed in two equal amounts and added after 30 and 45 days of sowing respectively. The observations were recorded on five randomly selected plants for days to 50 per cent flowering, node at which the first pod 
set, plant height $(\mathrm{cm})$, nodes per plant, internodal length $(\mathrm{cm})$, days to marketable maturity, pod length $(\mathrm{cm})$, pod diameter $(\mathrm{cm})$, ridges per pod, average pod weight $(\mathrm{g})$, pod yield per plant $(\mathrm{g})$, pods per plant, duration of availability of edible pods, dry matter (\%), mucilage (\%), immature pod colour and pod pubescence.

The mean values of the data collected were used for analysis of variance (Table 3) for RCBD was estimated (Panse and Sukhtame, 1984).

The phenotypic and genotypic coefficients of variation were estimated following Burton and De Vane, (1953) as follows:

Phenotypic coefficient of variation (PCV) $\%=\frac{\sigma p}{\bar{X}} \times 100$ Genotypic coefficient of variation (GCV) $\%=\frac{\sigma g}{\bar{X}} \times 100$

Where ${ }^{\sigma} \mathrm{p},{ }^{\sigma} \mathrm{g}$ and $\overline{\mathrm{X}}$ are phenotypic standard deviation, genotypic standard deviation, grand mean, respectively.

Heritability in broad sense $\left(\mathrm{h}^{2}{ }_{\text {bs }}\right)$ was calculated as per the following formula given by Burton and De Vane, (1953) and Johnson et al., (1955).

Heritability $\left(h^{2}{ }_{b s}\right)=\frac{\sigma^{-g}}{\sigma^{2} g+\sigma^{2} \mathrm{e}} \times 100$

Where, $\sigma^{2} \mathrm{~g}, \sigma^{2} \mathrm{e}$ and $\sigma^{2} \mathrm{~g}+\sigma^{2} \mathrm{e}$ are genotypic variance, environmental variance and phenotypic variances, respectively.

The expected genetic advance (GA) resulting from the selection of $5 \%$ superior individuals was calculated as per Burton and De Vane, (1953) and Johnson et al., (1955).

$\mathrm{GA}=\mathrm{K} \cdot \sigma \mathrm{p} \cdot \mathrm{h}^{2}{ }_{\mathrm{bs}}$
Where $\mathrm{K}=2.06$ (selection differential at $5 \%$ selection intensity), $\sigma \mathrm{p}=$ phenotypic standard deviation and $\mathrm{h}^{2}$ bs $=$ heritability (broad sense), respectively.

Genetic advance as percentage of mean (GA Expected GA

$\%)=\overline{\text { Grand mean }} \times 100$

Limits used for categorizing the magnitude of different parameters are presented in Table 1.

\section{Statistical analysis}

The mean values of different genotypes for various traits were statistically analysed using OPSTAT programme. OPSTAT (developed by CCS Haryana Agricultural University, Hisar, India) software was used for statistical analysis.

\section{Results and Discussion}

\section{Analysis of Variance}

The analysis of variance revealed that mean squares due to genotypes were significant for all the traits (Table 3) indicating the presence of good amount of genetic variability and considerable scope for improvement.

Sufficient genetic variability for many of the traits had also been reported by earlier workers with different genetic material under their environmental conditions (Sravanthi, 2017; Badiger and Yadav, 2018; Makhdoomi et al., 2018; Priyanka et al., 2018; Samim et al., 2018 and Syfullah et al., 2018).

The extent of variability present in the okra genotypes was measured in terms of mean, range, phenotypic (PCV) and genotypic (GCV) coefficients of variation, heritability (broad sense), genetic advance as per cent of mean for all the traits are presented in Tables 4,5 and 6. 


\section{Mean Performance of Genotype}

Genotype influenced some qualitative and quality traits (Table 4 and 6). Days to 50 per cent flowering and days to marketable maturity are the trait which determines the earliness of a variety and consequently help in capturing early market which fetches high price in markets, whereas pods per plant, pod length, pod diameter and weight are the major yield contributing traits. Based on mean values, genotypes viz., 9801 (45.33 days), DPO-2 (45.67 days), Kashi Vibhuti (46.33 days), DPO-1 (46.33 days), Palam Komal (46.33 days), DPO-20 (47.00 days), DPO-7 (47.33 days), Kashi Satdhari (47.67 days), Arka Anamika (47.67 days), DPO-13 (48.00 days), DPO-8 (48.33 days), DPO-19 (48.33 days), Punjab Suhawani (48.67 days), Kashi Pragati (49.00 days) and DPO-18 (49.00 days) were early in bearing 50 per cent flowering and genotypes viz., 9801 (49.67 days), DPO-1 (51.00 days), DPO-2 (51.00 days), Palam Komal (51.00 days), DPO-20 (51.67 days), Kashi Vibhuti (52.00 days), Kashi Satdhari (52.00 days), DPO-19 (52.00 days), DPO-13 (52.33 days), Punjab Suhawani (52.67 days), DPO-7 (52.67 days), DPO-8 (53.00 days), Kashi Pragati (53.33 days) and DPO-17 (53.33 days) took less number of days to marketable maturity. These results are in consonance with the findings of Kerure et al., (2017), Badiger and Yadav, (2018), Makhdoomi et al., (2018), Samim et al., (2018), Soni et al., (2018), Syfullah et al., (2018), Priyanka et al., (2018) and Kumar et al., (2019) for days to 50 per cent flowering, whereas Mallesh et al., (2015), Chandramouli et al., (2016), Chaudhary, (2016), Makhdoomi et al., (2018), Soni et al., (2018) and Priyanka et al., (2018) for days to marketable maturity.

Okra is grown during the rainy season, taller plants are preferred. In the present study maximum plant height was found in Punjab-8 $(159.00 \mathrm{~cm})$ followed by Punjab Suhawani
$(146.67 \mathrm{~cm})$, Kashi Vibhuti $(143.88 \mathrm{~cm})$, DPO-4 (143.47 cm) and Arka Anamika $(139.67 \mathrm{~cm})$. Among these 9801and Kashi Vibhuti also produced high marketable pods and pod yield. Higher pod yield in dwarf plants could be attributed to shorter intermodal length.

Genotypes having long duration of availability of edible pods are generally preferred in the present marketing system under Indian conditions because it not only avoids the glut in the market but off-season value of the crop is also maintained. Genotypes with long duration of availability of edible pods, in general, produced more pods and high pod yield per plant. In the present study, genotype DPO-5 offered promise for more pods per plant (14.00) and pod yield per plant (170.38 g) and thus suitable for longer duration (54.33 days) of availability of edible pods. Similar findings were also reported by Chandramouli et al., (2016) and Priyanka et al., (2018).

In present market, DPO-12 had maximum fruit length $(14.42 \mathrm{~cm})$ followed by Kashi Vibhuti $(14.05 \mathrm{~cm})$, DPO-10 $(13.84 \mathrm{~cm})$, DPO-9 $(13.69 \mathrm{~cm})$, DPO-16 $(13.64 \mathrm{~cm})$, Arka Anamika $(13.63 \mathrm{~cm})$, DPO-4 $(13.25 \mathrm{~cm})$ and Punjab-8 (13.09 cm). Bagwale et al., (2016), Pachiyappan and Sravannan, (2016), Badiger et al., (2017), Kerure et al., (2017), Makhdoomi et al., (2018) and Priyanka et al., (2018) had also reported the similar results. The genotypes had minimum pod diameter were DPO-12 $(1.26 \mathrm{~cm})$, Palam Komal (1.28 $\mathrm{cm})$, DPO-1 $(1.31 \mathrm{~cm})$, Punjab Suhawani $(1.33 \mathrm{~cm})$, DPO-3 $(1.33 \mathrm{~cm})$, DPO-7 (1.34 $\mathrm{cm})$, DPO-6 $(1.35 \mathrm{~cm})$, DPO-8 $(1.35 \mathrm{~cm})$ and DPO-14 $(1.35 \mathrm{~cm})$. The results are in conformity with the findings of Mallesh et al., (2015), Chaudhary, (2016), Kerure et al., (2017), Makhdoomi et al., (2018) and Priyanka et al., (2018) in okra in okra for pod diameter. Among the genotypes, Kashi Satdhari (9.87) exterted maximum ridges, 
whereas in all the genotypes 5-7 ridges was observed. Badiger et al., (2017) and Thulasiram et al., (2017) also reported similar results.

Higher pod yield is prime objective of all the crop improvement programmes. The genotypes 9801 (175.65 g), Kashi Vibhuti (172.65 g), DPO-5 (170.38 g), Palam Komal (168.14 g) and Punjab Suhawani (166.35 g) were the highest yielders. These findings are in conformity with Chaudhary, (2016), Badiger et al., (2017), Badiger and Yadav, (2018), Makhdoomi et al., (2018), Samim et al., (2018), Soni et al., (2018), Syfullah et al., (2018) and Priyanka et al., (2018). These genotypes were also among the five top genotypes for other economic traits such as nodes per plant, internodal length, days to marketable maturity, duration of availability of edible pods, pods per plant which were the main component traits contributing towards increased pod yield. Barring DPO-5, these genotypes also took the minimum days to 50 per cent flowering. The genotypes DPO-5 (14.00), 9801 (13.87), Kashi Vibhuti (13.67), Palam Komal (13.00) and Punjab Suhawani (12.33) produced the maximum pods per plant. Similar findings were recorded by Chaudhary, (2016), Badiger et al., (2017), Kerure et al., (2017), Badiger and Yadav, (2018), Makhdoomi et al., (2018), Soni et al., (2018), Syfullah et al., (2018) and Priyanka et al., (2018).

In general, the maximum pods per plant were recorded in those genotypes which had more nodes per plant and short internodal length. The maximum average pod weight was observed in the genotype DPO-11 (16.99 g) followed by Kashi Pragati (16.91 g), DPO-15 (16.73 g), Kashi Satdhari (15.90 g), DPO-19 (15.88 g), DPO-20 (14.94 g), DPO-17 (14.84 g), DPO-13 (14.56 g) and DPO-9 (14.47 g). These results are found to be similar with the findings of Badiger et al., (2017), Kerure et al., (2017), Badiger and Yadav, (2018), Makhdoomi et al., (2018), Samim et al., (2018), Soni et al., (2018), Syfullah et al., (2018) and Priyanka et al., (2018) in okra. Kashi Vibhuti and DPO-5 (15.33) had maximum nodes per plant followed by 9801 (15.20), Palam Komal (14.33) and Punjab Suhawani (13.67). The results are in broad conformity with the observations of Chaudhary, (2016), Kerure et al., (2017), Badiger and Yadav, (2018) and Priyanka et al., (2018) in okra. These genotypes had shorter internodal length of $9801(7.37 \mathrm{~cm})$, DPO-5 (8.11), DPO-10 (8.39 cm), Shitla Uphar $(8.55 \mathrm{~cm})$, DPO-8 $(8.75 \mathrm{~cm})$, Shitla Jyoti $(8.75 \mathrm{~cm})$, DPO-17 $(9.22 \mathrm{~cm})$, Kashi Vibhuti $(9.38 \mathrm{~cm})$, DPO-6 $(9.42 \mathrm{~cm})$, Palam Komal $(9.45 \mathrm{~cm})$, DPO-18 $(9.53 \mathrm{~cm})$ and Kashi Pragati $(9.55 \mathrm{~cm})$. Mallesh et al., (2015), Chandramouli et al., (2016), Chaudhary, (2016), Badiger et al., (2017), Badiger and Yadav, (2018), Makhdoomi et al., (2018), Samim et al., (2018), Soni et al., (2018) and Priyanka et al., (2018) have been reported the similar results.

For fresh consumption, okra pods with less dry matter content are preferred by the consumers. Among quality traits, minimum dry matter content was recorded in DPO-7 (5.72 \%), DPO-11 (5.81\%), Kashi Vibhuti (5.85\%), DPO-3 (5.94 \%), Punjab-8 (6.00\%), DPO-10 (6.03 \%), Kashi Pragati (6.09\%), DPO-6 (6.11 \%), DPO-1 (6.13\%), DPO-5 (6.18 \%), DPO-2 (6.37\%), DPO-17 (6.44 \%), DPO-19 (6.47 \%) and DPO-20 (6.49 \%). These findings are in close conformity with earlier workers for dry matter (Arora et al., 2008 and Bagwale et al., 2016). Okra mucilage is suitable for medicinal and industrial applications. It has found medically application as plasma replacement or blood volume expender. The mucilage or gelatinous outside coating and the fibre content found in okra are excellent in maintaining blood sugar levels. 
Table.1 Magnitude of differences for parameters

\begin{tabular}{|c|c|c|c|}
\hline & High (\%) & Moderate (\%) & Low (\%) \\
\hline PCV and GCV & More than 20 & $10-20$ & Less than 10 \\
\hline Heritability (\%) & More than 80 & $50-80$ & Less than 50 \\
\hline Genetic advance & More than 30 & $20-30$ & Less than 20 \\
\hline
\end{tabular}

Table.2 List of okra genotypes and their sources

\begin{tabular}{|c|c|}
\hline Genotype & Source \\
\hline Punjab Suhawani, Punjab-8 & $\begin{array}{l}\text { Punjab Agricultural University, Ludhiana } \\
\text { (Punjab) }\end{array}$ \\
\hline $\begin{array}{l}\text { Kashi Vibhuti, Kashi Pragati, Shitla Uphar, } \\
\text { Shitla Jyoti, Kashi Satdhari }\end{array}$ & $\begin{array}{l}\text { Indian Institute of Vegetable Research, } \\
\text { Varanasi (UP) }\end{array}$ \\
\hline $\begin{array}{l}\text { DPO-1, DPO-2, DPO-3, DPO-4, DPO-5, } \\
\text { DPO-6, DPO-7, DPO-8, DPO-9, DPO-10, } \\
\text { DPO-11, DPO-12, DPO-13, DPO-14, DPO- } \\
\text { 15, DPO-16, DPO-17, DPO-18, DPO-19, } \\
\text { DPO-20, 9801, Palam Komal }\end{array}$ & 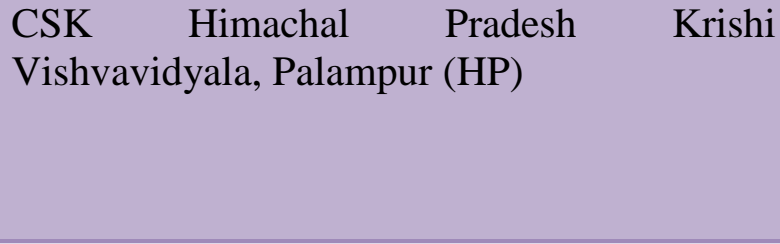 \\
\hline Arka Anamika & $\begin{array}{l}\text { Indian Institute of Horticultural Research, } \\
\text { Bangalore (Karnataka) }\end{array}$ \\
\hline
\end{tabular}

Table.3 Analysis of variance for quantitative and quality traits in okra genotypes

\begin{tabular}{|c|c|c|c|}
\hline Source of variation Traits df $\rightarrow$ & Replication 2 & $\begin{array}{l}\text { Treatment } \\
29\end{array}$ & Error 58 \\
\hline Days to $50 \%$ flowering & 13.144 & $14.131 *$ & 5.041 \\
\hline Node at which the first pod set & 0.028 & $0.174 *$ & 0.011 \\
\hline Plant height (cm) & 14.535 & $951.628 *$ & 47.363 \\
\hline Nodes per plant & 0.720 & $7.965 *$ & 1.127 \\
\hline Internodal length (cm) & 1.318 & $4.110 *$ & 0.908 \\
\hline Days to marketable maturity & 0.233 & $12.966^{*}$ & 5.337 \\
\hline Pod length (cm) & 1.811 & $3.792 *$ & 0.686 \\
\hline Pod diameter $(\mathrm{cm})$ & 0.006 & $0.023^{*}$ & 0.006 \\
\hline Ridges per pod & 0.007 & $2.377^{*}$ & 0.019 \\
\hline Average pod weight (g) & 2.683 & $10.853 *$ & 2.422 \\
\hline Pod yield per plant (g) & 27.969 & $1631.946^{*}$ & 31.060 \\
\hline Pods per plant & 0.700 & $9.134 *$ & 1.045 \\
\hline Duration of availability of edible pods & 7.233 & $43.176^{*}$ & 7.302 \\
\hline Dry matter (\%) & 0.122 & $0.811 *$ & 0.226 \\
\hline Mucilage (\%) & 0.001 & $0.090 *$ & 0.001 \\
\hline
\end{tabular}

*Significant at $5 \%$ level of significance 
Table.4 Estimates of mean values for quantitative and quality traits in okra genotypes

\begin{tabular}{|c|c|c|c|c|c|c|c|c|c|c|c|c|c|c|c|}
\hline $\begin{array}{l}\text { Genotypes/Tr } \\
\text { aits }\end{array}$ & DF & $\begin{array}{l}\text { NF } \\
\text { PS }\end{array}$ & $\begin{array}{l}\text { PH } \\
\text { (cm) }\end{array}$ & NPP & $\begin{array}{c}\mathrm{IL} \\
(\mathrm{cm})\end{array}$ & $\begin{array}{c}\text { DM } \\
\text { M }\end{array}$ & $\begin{array}{l}\text { PL } \\
(\mathbf{c m})\end{array}$ & $\begin{array}{l}\text { PD } \\
(\mathrm{cm})\end{array}$ & RPP & $\begin{array}{c}\mathbf{A P W} \\
(\mathbf{g})\end{array}$ & $\begin{array}{l}\text { PYPP } \\
(\mathrm{g})\end{array}$ & PPP & DAEP & $\begin{array}{l}\text { DM } \\
(\%)\end{array}$ & $\begin{array}{c}\text { M } \\
(\%)\end{array}$ \\
\hline $\begin{array}{l}\text { Punjab } \\
\text { Suhawani }\end{array}$ & 48.67 & 1.85 & 146.67 & 13.67 & 10.75 & 52.67 & 11.87 & 1.33 & 5.00 & 13.50 & 166.35 & 12.33 & 53.00 & 7.03 & 0.63 \\
\hline Kashi Vibhuti & 46.33 & 1.50 & 143.88 & 15.33 & 9.38 & 52.00 & 14.05 & 1.45 & 5.40 & 12.65 & 172.65 & 13.67 & 55.00 & 5.85 & 0.14 \\
\hline Kashi Pragati & 49.00 & 1.53 & 104.38 & 11.00 & 9.55 & 53.33 & 10.36 & 1.48 & 5.40 & 16.91 & 134.15 & 8.00 & 54.67 & 6.09 & 0.90 \\
\hline Shitla Uphar & 50.33 & 1.88 & 96.72 & 11.33 & 8.55 & 54.67 & 12.66 & 1.40 & 5.53 & 10.74 & 95.72 & 9.00 & 44.00 & 6.84 & 0.88 \\
\hline Shitla Jyoti & 50.67 & 1.52 & 104.67 & 12.00 & 8.75 & 55.00 & 12.12 & 1.50 & 5.03 & 11.83 & 113.69 & 9.67 & 49.67 & 6.59 & 0.57 \\
\hline Kashi Satdhari & 47.67 & 1.27 & 101.13 & 9.33 & 10.84 & 52.00 & 11.73 & 1.59 & 9.87 & 15.90 & 121.42 & 7.67 & 52.67 & 7.32 & 0.65 \\
\hline Arka Anamika & 47.67 & 2.02 & 139.67 & 11.67 & 11.98 & 53.67 & 13.63 & 1.52 & 5.73 & 12.71 & 122.45 & 9.67 & 49.33 & 6.72 & 0.68 \\
\hline DPO-1 & 46.33 & 1.50 & 134.67 & 11.67 & 11.56 & 51.00 & 10.91 & 1.31 & 5.16 & 12.17 & 120.69 & 10.00 & 55.33 & 6.13 & 0.91 \\
\hline DPO-2 & 45.67 & 1.19 & 109.63 & 9.90 & 11.15 & 51.00 & 12.65 & 1.40 & 5.00 & 13.83 & 109.31 & 8.00 & 46.00 & 6.37 & 0.94 \\
\hline DPO-3 & 55.00 & 1.92 & 134.41 & 11.27 & 12.03 & 59.33 & 12.12 & 1.33 & 4.90 & 11.98 & 103.07 & 8.67 & 40.33 & 5.94 & 0.57 \\
\hline DPO-4 & 51.33 & 1.47 & 143.47 & 13.00 & 11.11 & 56.67 & 13.25 & 1.41 & 5.10 & 11.13 & 116.36 & 10.67 & 50.67 & 6.76 & 0.61 \\
\hline DPO-5 & 49.33 & 1.13 & 124.33 & 15.33 & 8.11 & 53.67 & 12.05 & 1.46 & 5.00 & 12.22 & 170.38 & 14.00 & 54.33 & 6.18 & 0.56 \\
\hline DPO-6 & 49.67 & 1.28 & 115.41 & 12.33 & 9.42 & 54.33 & 11.05 & 1.35 & 5.03 & 11.86 & 126.10 & 10.67 & 52.67 & 6.11 & 0.82 \\
\hline DPO-7 & 47.33 & 1.33 & 104.67 & 10.00 & 10.53 & 52.67 & 12.74 & 1.34 & 5.13 & 14.07 & 110.94 & 8.00 & 53.67 & 5.72 & 0.65 \\
\hline DPO-8 & 48.33 & 1.43 & 98.43 & 11.33 & 8.75 & 53.00 & 12.38 & 1.35 & 4.83 & 10.46 & 99.90 & 9.67 & 48.00 & 7.53 & 0.78 \\
\hline DPO-9 & 52.00 & 1.72 & 129.90 & 12.33 & 10.54 & 56.67 & 13.69 & 1.47 & 5.07 & 14.47 & 147.84 & 10.33 & 50.33 & 7.54 & 0.91 \\
\hline DPO-10 & 49.67 & 1.62 & 107.92 & 12.92 & 8.39 & 54.00 & 13.84 & 1.45 & 5.00 & 10.06 & 109.58 & 11.00 & 46.33 & 6.03 & 0.70 \\
\hline DPO-11 & 50.33 & 1.98 & 110.40 & 11.00 & 10.07 & 55.33 & 11.99 & 1.41 & 4.97 & 16.99 & 151.02 & 9.00 & 46.00 & 5.81 & 0.73 \\
\hline DPO-12 & 50.00 & 1.50 & 134.77 & 11.50 & 11.80 & 54.67 & 14.42 & 1.26 & 5.40 & 12.11 & 112.60 & 9.33 & 49.67 & 6.59 & 0.60 \\
\hline DPO-13 & 48.00 & 1.63 & 101.60 & 9.60 & 10.75 & 52.33 & 12.32 & 1.44 & 5.20 & 14.56 & 111.17 & 7.67 & 50.33 & 7.03 & 0.55 \\
\hline DPO-14 & 51.67 & 1.40 & 105.67 & 9.67 & 10.95 & 55.00 & 12.04 & 1.35 & 5.00 & 12.20 & 93.43 & 7.67 & 44.33 & 7.27 & 0.65 \\
\hline DPO-15 & 49.67 & 1.31 & 97.67 & 10.00 & 9.79 & 53.67 & 11.27 & 1.39 & 5.53 & 16.73 & 144.76 & 8.67 & 50.67 & 6.89 & 0.49 \\
\hline DPO-16 & 50.00 & 1.34 & 114.33 & 10.33 & 11.05 & 54.67 & 13.64 & 1.50 & 5.40 & 12.38 & 101.51 & 8.33 & 49.67 & 6.55 & 0.69 \\
\hline DPO-17 & 49.33 & 1.57 & 102.67 & 11.17 & 9.22 & 53.33 & 12.22 & 1.40 & 5.03 & 14.84 & 136.69 & 9.33 & 46.00 & 6.44 & 0.49 \\
\hline DPO-18 & 49.00 & 1.50 & 113.33 & 11.92 & 9.53 & 54.00 & 10.70 & 1.39 & 5.10 & 12.44 & 123.73 & 10.00 & 48.67 & 6.93 & 0.72 \\
\hline DPO-19 & 48.33 & 1.23 & 129.33 & 11.47 & 11.40 & 52.00 & 10.82 & 1.49 & 4.93 & 15.88 & 157.65 & 10.00 & 52.33 & 6.47 & 0.45 \\
\hline DPO-20 & 47.00 & 1.77 & 107.47 & 9.58 & 11.46 & 51.67 & 12.12 & 1.48 & 5.00 & 14.94 & 118.43 & 8.00 & 52.67 & 6.49 & 0.78 \\
\hline 9801 & 45.33 & 1.27 & 112.03 & 15.20 & 7.37 & 49.67 & 10.40 & 1.49 & 5.00 & 12.66 & 175.65 & 13.87 & 53.33 & 7.08 & 0.58 \\
\hline $\begin{array}{l}\text { Palam Komal } \\
\text { (c) }\end{array}$ & 46.33 & 1.67 & 135.33 & 14.33 & 9.45 & 51.00 & 10.94 & 1.28 & 5.47 & 12.97 & 168.14 & 13.00 & 53.00 & 7.01 & 0.41 \\
\hline Punjab-8 (c) & 52.33 & 1.40 & 159.00 & 13.33 & 11.95 & 57.00 & 13.09 & 1.61 & 4.93 & 12.47 & 132.54 & 10.67 & 44.00 & 6.00 & 0.75 \\
\hline $\mathrm{SE}(\mathrm{m}) \pm$ & 1.30 & 0.06 & 3.97 & 0.61 & 0.55 & 1.30 & 0.48 & 0.04 & 0.08 & 0.90 & 3.22 & 0.59 & 1.56 & 0.27 & 0.02 \\
\hline $\operatorname{SE}(d) \pm$ & 1.83 & 0.09 & 5.62 & 0.87 & 0.78 & 1.84 & 0.68 & 0.06 & 0.11 & 1.27 & 4.55 & 0.84 & 2.21 & 0.39 & 0.03 \\
\hline C.V. (\%) & 4.58 & 6.99 & 5.82 & 9.13 & 9.27 & 4.19 & 6.77 & 5.34 & 2.60 & 11.72 & 4.40 & 10.54 & 5.43 & 7.23 & 5.66 \\
\hline C.D. $5 \%$ & 3.68 & 0.18 & 11.28 & 1.74 & 1.56 & 3.68 & 1.36 & 0.12 & 0.23 & 2.55 & 9.13 & 1.68 & 4.43 & 0.78 & 0.06 \\
\hline Grand Mean & 49.08 & 1.52 & 118.35 & 11.62 & 10.28 & 53.67 & 12.24 & 1.41 & 5.31 & 13.28 & 126.77 & 9.70 & 49.77 & 6.58 & 0.66 \\
\hline
\end{tabular}

DF-days to 50 per cent flowering, NFPS-node at which the first pod set, PH-plant height, NPP-nodes per plant, ILinternodal length, DMM-days to marketable maturity, PL-pod length, PD-pod diameter, RPP-ridges per pod, APWaverage pod weight, PYPP-pod yield per plant, PPP-pods per plant, DAEP-duration of availability of edible pods, DM-dry matter, M-mucilage 
Table.5 Estimate of genetic parameters for quantitative and quality traits in okra genotypes

\begin{tabular}{|c|c|c|c|c|c|c|}
\hline Traits & $\begin{array}{c}\text { Grand } \\
\text { Mean } \pm \mathrm{SE}(\mathrm{m})\end{array}$ & Range & $\begin{array}{c}* P C V \\
(\%)\end{array}$ & $\begin{array}{c}* * \mathbf{G C V} \\
(\%)\end{array}$ & $\begin{array}{l}\# h^{2} \\
(\%)\end{array}$ & $\begin{array}{c}{ }^{ \pm} \text {GA as percent } \\
\text { of mean }\end{array}$ \\
\hline Days to $50 \%$ flowering & $49.08 \pm 1.30$ & $45.33-55.00$ & $5.79(\mathrm{~L})$ & $3.55(\mathrm{~L})$ & $37.54(\mathrm{~L})$ & $4.48(\mathrm{~L})$ \\
\hline $\begin{array}{l}\text { Node at which the first } \\
\text { pod set }\end{array}$ & $1.52 \pm 0.06$ & $1.13-2.02$ & $16.78(\mathrm{M})$ & $15.26(\mathrm{M})$ & $82.65(\mathrm{H})$ & $28.57(\mathrm{M})$ \\
\hline Plant height (cm) & $118.35 \pm 3.97$ & $96.72-159.00$ & $15.78(\mathrm{M})$ & $14.67(\mathrm{M})$ & $86.42(\mathrm{H})$ & $28.09(\mathrm{M})$ \\
\hline Nodes per plant & $11.62 \pm 0.61$ & $9.33-15.33$ & $15.88(\mathrm{M})$ & $12.99(\mathrm{M})$ & $66.92(\mathrm{M})$ & $21.89(\mathrm{M})$ \\
\hline Internodal length $(\mathrm{cm})$ & $10.28 \pm 0.55$ & $8.11-12.03$ & $13.67(\mathrm{M})$ & $10.05(\mathrm{M})$ & $54.03(\mathrm{M})$ & $15.21(\mathrm{~L})$ \\
\hline $\begin{array}{l}\text { Days to marketable } \\
\text { maturity }\end{array}$ & $53.67 \pm 1.30$ & $49.67-59.33$ & $5.17(\mathrm{~L})$ & $3.03(\mathrm{~L})$ & $34.31(\mathrm{~L})$ & $3.65(\mathrm{~L})$ \\
\hline Pod length $(\mathrm{cm})$ & $12.24 \pm 0.48$ & $10.36-14.42$ & $10.72(\mathrm{M})$ & $8.32(\mathrm{~L})$ & $60.14(\mathrm{M})$ & $13.28(\mathrm{~L})$ \\
\hline Pod diameter $(\mathrm{cm})$ & $1.41 \pm 0.04$ & $1.26-1.61$ & $7.55(\mathrm{~L})$ & $5.34(\mathrm{~L})$ & $49.95(\mathrm{~L})$ & $7.77(\mathrm{~L})$ \\
\hline Ridges per pod & $5.31 \pm 0.08$ & $4.83-9.87$ & $16.90(\mathrm{M})$ & $16.70(\mathrm{M})$ & $97.64(\mathrm{H})$ & $34.00(\mathrm{H})$ \\
\hline $\begin{array}{l}\text { Average pod weight } \\
\text { (g) }\end{array}$ & $13.28 \pm 0.90$ & $10.06-16.99$ & $17.22(\mathrm{M})$ & $12.62(\mathrm{M})$ & $53.70(\mathrm{M})$ & $19.05(\mathrm{~L})$ \\
\hline Pod yield per plant (g) & $126.77 \pm 3.22$ & $99.90-172.65$ & $18.75(\mathrm{M})$ & $18.22(\mathrm{M})$ & $94.50(\mathrm{H})$ & $36.49(\mathrm{H})$ \\
\hline Pods per plant & $9.70 \pm 0.59$ & $7.67-14.00$ & $19.94(\mathrm{M})$ & $16.93(\mathrm{M})$ & $72.07(\mathrm{M})$ & $29.61(\mathrm{M})$ \\
\hline $\begin{array}{l}\text { Duration of } \\
\text { availability of edible } \\
\text { pods }\end{array}$ & $49.77 \pm 1.56$ & $40.33-55.33$ & $8.82(\mathrm{~L})$ & $6.95(\mathrm{~L})$ & $62.09(\mathrm{M})$ & $11.28(\mathrm{~L})$ \\
\hline Dry matter (\%) & $6.58 \pm 0.27$ & $5.72-7.54$ & $9.86(\mathrm{~L})$ & $6.71(\mathrm{~L})$ & $46.34(\mathrm{~L})$ & $9.41(\mathrm{~L})$ \\
\hline Mucilage (\%) & $0.66 \pm 0.02$ & $0.14-0.94$ & $26.65(\mathrm{H})$ & $26.04(\mathrm{H})$ & $95.50(\mathrm{H})$ & $52.42(\mathrm{H})$ \\
\hline
\end{tabular}

PCV = Phenotypic coefficient of variation

${ }^{* *} \mathrm{GCV}=$ Genotypic coefficient of variation

${ }^{*} \mathrm{~h}^{2}=$ Heritability

${ }^{ \pm} \mathrm{GA}=$ Genetic Advance

$\mathrm{H}=$ High, $\mathrm{M}=$ Medium, $\mathrm{L}=$ Low

Table.6 Mean performance of top high yielding genotypes for qualitative and quality traits in okra

\begin{tabular}{|c|c|c|c|c|c|c|c|}
\hline \multirow{2}{*}{$\begin{array}{l}\text { Sr. } \\
\text { No }\end{array}$} & \multirow[t]{2}{*}{ Traits } & \multicolumn{6}{|c|}{ Mean performance of top ranking genotypes along with check } \\
\hline & & 9801 & $\begin{array}{c}\text { Kashi } \\
\text { Vibhuti }\end{array}$ & DPO-5 & $\begin{array}{l}\text { Palam Komal } \\
\text { (check) }\end{array}$ & $\begin{array}{l}\text { Punjab } \\
\text { Suhawani }\end{array}$ & $\begin{array}{c}\text { Punjab-8 } \\
\text { (check) }\end{array}$ \\
\hline 1 & Days to 50 per cent flowering & 45.33 & 46.33 & 49.33 & 46.33 & 48.67 & 52.33 \\
\hline 2 & Node at which the first pod set & 1.27 & 1.50 & 1.13 & 1.67 & 1.85 & 1.40 \\
\hline 3 & Plant height (cm) & 112.03 & 143.88 & 124.33 & 135.33 & 146.67 & 159.00 \\
\hline 4 & Nodes per plant & 15.20 & 15.33 & 15.33 & 14.33 & 13.67 & 13.33 \\
\hline 5 & Internodal length $(\mathrm{cm})$ & 7.37 & 9.38 & 8.11 & 9.45 & 10.75 & 11.95 \\
\hline 6 & Days to marketable maturity & 49.67 & 52.00 & 53.67 & 51.00 & 52.67 & 57.00 \\
\hline 7 & Pod length (cm) & 10.40 & 14.05 & 12.05 & 10.94 & 11.87 & 13.09 \\
\hline 8 & Pod diameter $(\mathrm{cm})$ & 1.49 & 1.45 & 1.46 & 1.28 & 1.33 & 1.61 \\
\hline 9 & Ridges per pod & 5.00 & 5.40 & 5.00 & 5.47 & 5.00 & 4.93 \\
\hline 10 & Average pod weight (g) & 12.66 & 12.65 & 12.22 & 12.97 & 13.50 & 12.47 \\
\hline 11 & Pod yield per plant (g) & $\mathbf{1 7 5 . 6 5}$ & 172.65 & 170.38 & 168.14 & 166.35 & 132.54 \\
\hline 12 & Pods per plant & 13.87 & 13.67 & 14.00 & 13.00 & 12.33 & 10.67 \\
\hline 13 & $\begin{array}{l}\text { Duration of availability of edible } \\
\text { pods }\end{array}$ & 53.33 & 55.00 & 54.33 & 53.00 & 53.00 & 44.00 \\
\hline 14 & Dry matter $(\%)$ & 7.08 & 5.85 & 6.18 & 7.01 & 7.03 & 6.00 \\
\hline 15 & Mucilage (\%) & 0.58 & 0.14 & 0.56 & 0.41 & 0.63 & 0.75 \\
\hline
\end{tabular}


Higher mucilage content was found in DPO-2 (0.94 \%), DPO-1 (0.91\%), DPO-9 (0.91\%), Kashi Pragati $(0.90 \%)$ and Shitla Uphar $(0.88$ $\%)$. Woolfe et al., (1977) and Arora et al., (2008) have also reported almost similar findings for the mucilage extraction and estimation in okra.

\section{Parameters of Variability}

Variability was partitioned into genotypic and environmental components. The estimates of PCV were higher than corresponding GCV for all the characters studied (Table 5) which indicated that the apparent variation is not only due to genotypes but also due to the influence of environment. However, the differences between the genotypic and phenotypic variances were relatively low for most of the traits studied. This indicated highly heritable and comparatively stable nature of the characters and thus, the selection based on phenotypic performance would be quite effective in the improvement of these traits.

The magnitude of PCV and GCV were high for mucilage (26. $65 \%$ and $26.04 \%$ ) indicated that there is substantial variability ensuring ample scope for improvement of this trait through selection. It was moderate for pods per plant (19.94 \% and $16.93 \%)$ followed by pod yield per plant $(18.75 \%$ and $18.22 \%)$, average pod weight $(17.22 \%$ and $12.62 \%)$, ridges per pod $(16.90 \%$ and 16.70 $\%)$, node at which the first pod set $(16.78 \%$ and $15.26 \%)$, nodes per plant $(15.88 \%$ and $12.99 \%)$, plant height $(15.78 \%$ and $14.67 \%)$ and internodal length (13.67 \% and $10.05 \%)$. GCV was also moderate for pod length (10.72 $\%)$. The moderate estimates suggested cautions approach while following direct selection for these traits. Such moderate estimates have also been reported by earlier researchers Badiger et al., (2017), Kerure et al., (2017), Sravanthi, (2017), Badiger and
Yadav, (2018), Makhdoomi et al., (2018), Syfullah et al., (2018) and Priyanka et al., (2018) in okra.

The rest of the traits namely, days to marketable maturity $(5.17 \%$ and $3.03 \%)$, days to 50 per cent flowering $(5.79 \%$ and $3.55 \%)$, pod diameter $(7.55 \%$ and $5.34 \%$ ) and duration of availability of edible pods (8.82 \% and $6.95 \%$ ) showed low PCV and GCV estimates. GCV was also low for pod length $(8.32 \%)$. These traits can be improved through hybridization. The low estimates have also been reported by Karri and Acharyya, (2012) and Samim et al., (2018) for pod diameter, who used different genetic material and were in different environments, indicating the possibility for improvement through hybridization for these traits.

\section{Heritability and Genetic Advance}

Heritability in broad sense is a parameter of tremendous significance to the breeders as its magnitude indicates the reliability with which a genotype can be recognized by its phenotypic expression.

Most of the traits studied showed high (>80 $\%)$ to moderate $(50-80 \%)$ heritability. The Heritability (in broad sense) estimates were recorded to be high for ridges per pod (97.64 $\%)$ followed by mucilage $(95.50 \%)$, pod yield per plant $(94.50 \%)$, plant height $(86.42$ $\%)$ and node at which the first pod set $(82.65$ $\%$ ) indicating that these traits were less influenced by the environment. This suggested that the large proportion of phenotypic variance has been attributed to the genotypic variance and hence, reliable selection could be made for these traits on the basis of phenotypic expression. In okra higher estimates of heritability had also been found by earlier workers for pod yield per plant (Kandasamy, 2015; Mallesh et al., 2015; Chandramouli et al., 2016; Badiger and 
Yadav, 2018; Makhdoomi et al., 2018; Soni et al., 2018 and Syfullah et al., 2018) and plant height (Badiger and Yadav, 2018 and Syfullah et al., 2018).

Johnson et al., (1955) stressed that for estimating the real effects of selection, heritability alone is not sufficient and genetic advance along with heritability is more useful.

High heritability along with high genetic advance observed for ridges per pod (97.64\% and $34.00 \%$ ), mucilage (95.50\% and 52.42 $\%)$ and pod yield per plant $(94.50 \%$ and $36.49 \%$ ), whereas high to moderate heritability coupled with moderate genetic advance for plant height (86.42\% and 28.09), node at which the first pod set $(82.65 \%$ and $28.57 \%$ ), pods per plant $(72.07 \%$ and 29.61 $\%)$ and nodes per plant (66.92\% and 21.89 $\%)$. High to moderate heritability coupled with high to moderate genetic advance indicates preponderance of additive gene action which implies that these traits can be improved through pure line selection. The findings are in line for pod yield per plant (Badiger and Yadav, 2018; Makhdoomi et al., 2018, Soni et al., 2018 and Syfullah et al., 2018).

Moderate heritability with low genetic advance noticed for the traits duration of availability of edible pods (62.09\% and 11.28 $\%)$, pod length (60.14 \% and $13.28 \%)$, internodal length (54.03\% and $15.21 \%$ ) and average pod weight $(53.70 \%$ and $19.05 \%)$. Low heritability was found to be associated with low genetic advance for days to marketable maturity (34.31\% and $3.65 \%)$, days to 50 per cent flowering $(37.54 \%$ and $4.48 \%)$, dry matter (46.34\% and $9.41 \%)$ and pod diameter $(49.95 \%$ and $7.77 \%)$. The association of moderate to low heritability with low genetic advance in these characters suggests the preponderance of non-additive gene action and consequently improvement of these traits through recombination breeding is possible. Improvement of these traits through straight selection might not give desirable results. Similar results were obtained by earlier workers in case of pod diameter (Karri and Acharyya, 2012 and Samim et al., 2018) using different genetic material and under different environmental conditions.

There was adequate genetic variability within the germplasm evaluated for the improvement of marketable pod yield and quantitative and qualitative traits. The genetic variation observed suggests that a positive response to direct selection is possible for ridges per pod, mucilage, pod yield per plant, pods per plant and nodes per plant as these traits showed high to moderate heritability and genetic advance.

\section{References}

Adunga, W and Labuschangne, M.T. 2003. Association of linseed characters and its variability in different environment. Journal of Agricultural Science. 14: 285-296.

Anonymous. 2016(a). Food and Agriculture Organization Statistics (FAOSTAT), United States. http://www.faostat.org/

Anonymous. 2016(b). Package of practices for kharif crops of Himachal Pradesh, Himachal Pradesh Krishi Vishvavidyalaya, Palampur

Anonymous. 2017. Area and production of vegetables in Himachal Pradesh. Department of Agriculture (HP), Shimla-5

Anonymous. 2018. Indian Horticulture Database. National Horticulture Board, Ministry of Agriculture, Government of India, Gurgaon, India

Arora, D.S., Kumar and Ghai, T.R. 2008. Gene action for some biochemical traits in okra (Abelmoschus esculentus (L.) Moench). Vegetable Science. 35: 180-184.

Badiger, $M$ and Yadav, R.K. 2018. Genetic variability and association of yield with its component traits in okra. Indian Journal of Horticulture. 75: 713-716. 
Badiger, M., M., Pitchaimuthu and Pujer, P. 2017. Genetic variability, heritability, genetic advance and correlation studies among quantitative traits in okra (Abelmoschus esculentus (L.) Moench). Global Journal of Bio-science and Biotechnology. 6: 314-319.

Bagwale, S.B., L.N., Jawal, D.B., Deosarkar and Jadhav, R.A. 2016. Genetic variability studies for yield, yield contributing and quality traits in okra (Abelmoschus esculentus (L.) Moench). Indian Journal of Agricultural Research. 50: 614-618.

Burton, G.W and De Vane, E.H. 1953. Estimating heritability in tall fescue (Festuca arundinaceae) from replicated clonal material. Agronomy Journal. 54: 478-481.

Chandramouli, B., D., Shrihari, AVDD, Rao and Rao, MP. 2016. Studies on genetic variability, heritability and genetic advance in okra (Abelmoschus esculentus (L.) Moench) genotypes. Plant Archives. 16: 679-682.

Choudhary, B. 2016. Genetic analysis of yield and components in okra (Abelmoschus esculentus (L.) Moench). M.Sc. Thesis, p 57. Department of Horticulture, Institute of Agriculture Science, Banaras Hindu University, India

Clopton, J.R., A., Roberts and Jeskey, H.D. 1948. Chemical studies on oil bearing seeds in okra. Journal of the American Oil Chemists' Society. 25: 401-404.

Fisher, R.A. 1918. The correlation between the relatives on the supposition of Mendelian inheritance. Translated from Royal Science of Education. 52: 399-433.

Gemede, H.F., N., Ratta, G.D., Haki, Z., Ashagrie, Woldegiorgis and Beyene, F. 2015. Nutritional quality and health benefits of okra (Abelmoschus esculentus): A review. International Journal of Nutrition and Food Sciences. 4: 208-215.

Johnson, H.W., H.F., Robinson and Comstock R.E. 1955. Estimates of genetic and environmental variability in soybean. Agronomy Journal. 47: 314-318.

Kandasamy, R. 2015. Variability studies in okra Abelmoschus esculentus (L.). The Asian Journal of Horticulture. 10: 60-63.

Karakoltisidis, P.A and Constandinides. 1975. Okra Seeds. A new protein source. Journal of Agricultural and Food Chemistry. 23: 1204-1207.

Karri, S.R and Acharyya, P. 2012. Performance of okra (Abelmoschus esculentus (L.) Moench) cultivars under summer and rainy environments. International Journal of advanced Life Sciences. 2: 16-21.

Kerure, P., M., Pitchaimuthu and Hosamani, A. 2017. Studies on variability, correlation and path analysis of traits contributing to fruit yield and its components in okra (Abelmoschus esculentus (L.) Moench). Electronic Journal of Plant Breeding. 8: 134-141.

Khajuria, R.K., J.P., Sharma, R.K., Samnotra, S., Kumar and Ranjit, K. 2015. Variability studies in okra (Abelmoschus esculentus (L.) Moench). Electronic Journal of Plant Breeding. 7: 226-234.

Kumar, A., M., Kumar, V.R., Sharma, M.K., Singh, B., Singh and Chand, P. 2019. Character association and path coefficient analysis of yield and yield related traits in okra (Abelmoschus esculentus (L.) Moench). Progressive Agriculture. 19: 140145.

Makhdoomi, M.I., K.P., Wani, N., Jabeen, A., Nabi, B., Afroza, K., Hussain and Singh, P.K. 2018. Variability analysis in okra (Abelmoschus esculentus (L.) Moench). Journal of Pharmacognosy and Phytochemistry. 7: 177-180.

Mallesh, S., S., Revanappa, B., Shivashankar, B., Prabhakar and Mangi, V. 2015. Genetic variability studies in okra (Abelmoschus esculentus (L.) Moench). International Quarterly Journal of Life Sciences. 10: 2081-2084.

Markose, B.L and Peter K.V. 1990. Review of research on vegetables and tuber crops (okra). Directorate of Extension, Kerala Agricultural University Mannuthy. 101: 549-558.

Martin, F.W. 1982. Okra, potential multiplepurpose crop for temperate zones and tropics. Economic Botony. 36(3): 340-345.

Martin, F.W., R.M., Rhodes, M., Ortiz and Diaz F. 1981. Variation in okra. Euphytica. 30: 697-705.

Morey, A.L., P.K., Nagre, V.N., Dod and Kale, V.S. 2012. Genetic variability in okra. 
Asian Journal of Horticulture. 7: 1-4.

OPSTAT computer programming for data analysis. hau.ernet.in

Pachiyappan, R and Saravannan, K. 2016. Studies on genetic variability and correlation for fruit yield and fruit quantity characters of okra. The Asian Journal of Horticulture. 1: 101-104.

Panse, V.G and Sukhatme, P.V. 1984. Statistical Methods for Agricultural Workers. ICAR (Indian Council of Agricultural Research), New Delhi. p 381.

Patil, B.T., V.R., Rode, M.N., Bhalekar and Shinde, K.G. 2016. Correlation and path analysis studies in okra (Abelmoschus esculentus (L.) Moench). Vegetable Science. 43: 226-229.

Priyanka, V.D., T.M., Reddy, H., Begum, N., Sunil and Jayaprada, M. 2018. Studies on genetic variability, heritability and genetic advance in genotypes of okra (Abelmoschus esculentus (L.) Moench). International Journal of Current Microbiology and Applied Sciences.7: 401-411.

Robinson, H.F., R.E., Comstock and Harvey, P.H. 1949. Estimates of heritability and degree of dominance in corn. Agronomy Journal. 41: 253-259.

Samim, S., S., Sood and Singh, A. 2018. Genetic assessment for fruit yield and horticultural traits in okra (Abelmoschus esculentus (L.) Moench). International Journal of Current Microbiology and Applied Sciences. 7: 947-957.

Soni, O.M., P.K., Jain and Sharma, N. 2018. Genetic variability, correlation and path analysis in okra. International Journal of
Applied Agricultural \& Horticultural Sciences. 9: 430-433.

Sravanthi, U. 2017. Studies on variability, heritability and genetic advance in okra (Abelmoschus esculentus (L.) Moench). International Journal of Current Microbiology and Applied Sciences. 10: 834-1838.

Syfullah, K., S.O., Nasif, M.S., Islam, N.H., Sani, S., Parvin and Sarowar,.2018. Genetic variability, heritability, character association and morphological diversity in okra (Abelmoschus esculentus (L.) Moench). International Journal of Plant and Soil Science. 25: 1-11.

Thamburaj, S and Singh, N. 2001. Vegetables, Tuber crops and Spices. Directorate of information and publications of agriculture, ICAR (Indian Council of Agricultural Research), New Delhi. p 222.

Thulasiram, L.B., S.R., Bhople, M., Srikanth and Nayak, B.R. 2017. Genetic variability and heritability studies in okra (Abelmoschus esculentus (L.) Moench). Plant Archives. 17: 907-910.

Vavilov, N.I. 1951. The origin, variation, immunity and breeding of cultivated plants. (Translated from Russian by Chester KS). Chronical Botany. 13: 1-364.

Woolfe, M.L., M.F., Chaplin and Otchere, G. 1977. Studies on the mucilages extracted from okra fruits (Abelmoschus esculentus (L.) Moench) and baobab leaves Adansonia digitata (L.). Journal of Science Federation of Agriculture. 28: 519-529.

\section{How to cite this article:}

Amandeep Kaur, Sonia Sood, V.K. Sood, Sanjay Chadha and Akhilesh Singh. 2019. Genetic Analysis of Quantitative and Quality Traits in Okra under Sub-Temperate Conditions of NorthWestern Himalayas. Int.J.Curr.Microbiol.App.Sci. 8(08): 492-504. doi: https://doi.org/10.20546/ijcmas.2019.808.057 